Маланчук П.

Проблеми кримінальної відповідальності юридичних осіб

DOI:

УДК 343.222

\title{
Петро Маланчук,
}

кандидат юридичних наук, доиент кафедри правосуддя юридичного факультету Сумського національного аграрного університету ORCID: http://orcid.org/0000-0002-4501-708X

\section{ПРОБЛЕМИ КРИМІНАЛЬНӦ̈ ВІДПОВІДАЛЬНОСТІ ЮРИДИЧНИХ ОСІБ}

\begin{abstract}
Проаналізовано доктринальні положення кримінального права України. Розглянуто питання про невідповідність міжнародних стандартів у галузі кримінального права і традиційних підходів до основних інститутів кримінального права України. Розкрито питання теоретичного та практичного застосування кримінальної відповідальності щодо юридични осіб з урахуванням досвіду кримінального законодавства. Пропонуються шляхи вдосконалення національного кримінального законодавства з урахуванням зарубіжного досвіду. Проблема кримінальної відповідальності юридичних осіб донині залишається дискусійною. Питання про дочільність запровадження такої відповідальності набуло актуальності після прийняття Верховною радою Украӥни Закону України від 23 травня 2013 р. «Про внесення змін до деяких законодавчих актів України щзодо виконання Плану дій щзодо лібералізаиії Свропейським Союзом візового режиму для Украӥни стосовно відповідальності юридичних осіб». Зокрема, положеннями цього закону передбачається застосування до юридичних осіб заходів кримінально-правового характеру.
\end{abstract}

Ключові слова: юридичні особи, суб’єкт злочину, кримінальна відповідальність, кримінальний кодекс, покарання.

Бібл.: 6.

Маланчук П.

Проблемы уголовной ответственности юридических лиц

Проанализировпно доктринальные положения уголовного права Украины. Рассматривается вопрос о несоответствии международным стандартам в области уголовного права и традиционных подходов к основным институтам уголовного права Украиныл. Раскрыто вопросы теоретического и практического применения уголовной ответственности в отношении юридических лиц с учетом опьта уголовного законодательства. Предлагаются пути совершенствования национального уголовного законодательства с учетом зарубежного опыта. Проблема уголовной ответственности юридических лии по сей день остается дискуссионной. Вопрос о ияелесообразности введения такой ответственности приобрел актуальность после принятия Верховной Радой Украины Закона Украины от 23 мая 2013 «О внесении изменений в некоторые законодательные акты Украины относительно выполнения Плана действий по либерализации Европейским Союзом визового режима для Украины относительно ответственности юридических лицу». В частности, положениями данного закона предусматривается применение к юридическим лииам мер уголовно-правового характера.

Ключевые слова: юридические лииа, субъект преступления, уголовная ответственность, уголовный кодекс, наказание.

\section{Malanchuk $P$.}

Problems of criminal liability of legal entities

The doctrinal provisions of the criminal law of Ukraine are analyzed. The issue of non-compliance with international standards in the field of criminal law and traditional approaches to the main institutions of criminal law of Ukraine is considered. The article discusses the theoretical and practical application of criminal liability in relation to legal entities, taking into account the experience of criminal law. Ways are proposed to improve national criminal legislation, taking into account foreign experience. The problem of criminal liability of legal entities to this day remains debatable. The question of the appropriateness of introducing such responsibility became relevant after the adoption by the Verkhovna Rada of Ukraine of the Law of Ukraine of May 23, 2013 "On Amending Certain Legislative Acts of Ukraine Concerning the Implementation of the Action Plan for the Liberalization of the European Union Visa Regime for Ukraine Regarding the Liability of Legal Entities". In particular, the provisions of this law provide for the application of criminal measures to legal entities. Measures of criminal nature can be applied to subjects privately and public law, residents and non-residents; Dents of Ukraine, including enterprises, establishments new or organizations, government

(C) Петро Маланчук, 2020 
Кримінальне право та кримінологія. Кримінально-виконавче право. Кримінальний процес та криміналістика. Судова експертиза. Оперативно-розшукова діяльність. Судоустрій. Прокуратура та адвокатура.

bodies, bodies the authorities of the ARC, local governments, organizations certified by them in the appropriate orderfunds, international organizations and others legal entities created in accordance with the requirements of national or international law. As a rule, legal entities apply-material measures are taken and all problems can be solved (and they are solved) in within other areas of law. For legal a special system of penalties was created which, in essence, they are not criminal penalties. That is why under the Criminal Code of Ukraine to legal entities criminal law measures are applied character: fine, confiscation of property, liquidation. Therefore, to ensure that the relevant rules are effective The Criminal Code of Ukraine should be studied internationally experience and its implementation in the national criminal legislation.

Keywords: legal entities, subject of crime, criminal liability, criminal code, punishment.

Постановка проблеми. Однією з найбільш актуальних проблем, що обговорюються у період проведення кримінально-правових реформ у сучасних державах світу, зокрема державах, які утворені у пострадянському просторі, є проблема кримінальної відповідальності юридичних осіб. Актуальність цієї дискусійної теми пов'язують, по-перше, з відсутністю дієвих механізмів відновлення порушених прав юридичною особою. По-друге, в Україні дуже гостро постає питання про стягнення проблемної заборгованості з юридичних осіб, що виникає у зв’язку з неможливістю результативно впливати на дії юридичної особи в межах правового поля. По-третє, як свідчить практика, більшість злочинів вчиняється саме за допомогою юридичних осіб.

Аналіз останніх досліджень і публікацій. Питання визнання юридичної особи суб'єктом злочину досліджували такі вчені: Р. В. Вереша, В. А. Власіхіна, Б. В. Волженкін, С. Б. Гавриш, У. С. Джекабаєв, С. Г. Кєліна, І. Д. Козочкін,. .В.Красницький, В. М. Кудрявцев, В. В. Лунєєв, О. О. Міхайлов, А. В. Наумов, А. С. Нікіфоров, С. І. Нікулін, І. В. Сітковський, В. Н. Смітієнко, В. С. Устінов, П. Л. Фріс та ін. Однак проблема визнання юридичної особи суб'єктом злочину у нашій державі наразі не вирішена.

Метою дослідження є обгрунтування доцільності та можливості притягнення до кримінальної відповідальності юридичних осіб, з'ясування правової природи заходів кримінально-правового характеру щодо юридичних осіб.

Виклад основного матеріалу дослідження. Найбільш складним і проблемним є питання про кримінальну відповідальність юридичних осіб. 31 вересня 2014 р. набув чинності Закон України від 23 травня 2013 р. «Про внесення змін до деяких законодавчих актів України у зв>язку з виконанням Плану дій щодо лібералізації Європейським Союзом візового режиму для України щодо відповідальності юридичних осіб». Цим же Законом Загальну частину КК України доповнено розділом XIV-1 «Заходи кримінально-правового характеру щодо юридичних осіб».

На сьогодні кримінальна відповідальність юридичних осіб встановлена у Нідерландах, Португалії, Фінляндії, Китаї, США, Канаді, Великобританії, Шотландії, Данії, Люксембургу. У таких країнах, як Німеччина, Швеція, Італія та Іспанія, встановлено так звану квазікримінальну (за суттю адміністративнокримінальну) відповідальність юридичних осіб.

Проблемними на сьогодні є такі питання:

- юридичні особи не можуть підлягати кримінальній відповідальності внаслідок неможливості визначення вини такої особи у скоєнні кримінального правопорушення, відсутності науково обгрунтованої системи кримінальних покарань юридичних осіб тощо;

- кримінальна відповідальність юридичних осіб не відповідає фундаментальним принципам кримінального права, зокрема принципу особистої винної відповідальності та принципу індивідуалізації кримінальної відповідальності і покарання;

- встановлення кримінальної відповідальності юридичних осіб лише із загально-превентивною метою є недоцільним, оскільки у законі і без цього є значна кількість норм, що мають попереджувальний характер.

На думку професора С. Келіна, притягнення фізичної особи до кримінальної відповідальності за вчинений злочин часто не змінює ситуацію на краще, оскільки злочинна діяльність організації все ще наявна, а шкода, яку спричиняють юридичні особи під час вчинення злочину, часто не відповідає тяжкості кримінальних покарань, а також тим санкціям, які застосовуються до них у рамках інших видів юридичної відповідальності [1].

Ще однією проблемою є зміна власника юридичної особи. Так, вищезазначеним законом не передбачено будь-яких винятків, спрямованих на захист інтересів нового власника юридичної особи, у разі притягнення такої юридичної особи до відповідальності за кримінальні правопорушення, вчинені їі попереднім власником [2]. 
Щодо зарубіжного досвіду, то згідно з КК Франції юридичні особи можуть бути притягнуті до кримінальної відповідальності самостійно чи спільно із фізичними особами; нести відповідальність як за закінчений злочин, так і за попередню злочинну діяльність. Цьому інституту характерні риси обумовленості (злочинне діяння має бути вчинене на користь юридичної особи його керівником або представником) та спеціальності (кримінальна відповідальність настає тільки у випадках, спеціально передбачених законом або ухвалою) [3, с. 76-77].

У зарубіжній практиці загалом склалися 3 концепції розуміння кримінальної відповідальності юридичних осіб, серед яких: а) повне заперечення інституту кримінальної відповідальності юридичних осіб (Болгарія, Угорщина, Польща); повне визнання інституту кримінальної відповідальності юридичної особи (Франція, КНР, Литва, Молдова); застосування непрямої кримінальної відповідальності юридичних осіб. (Німеччина, Австрія) [4].

У Китаї існує теорія взаємозв’язку кримінальної відповідальності - підставою кримінальної відповідальності є принципи взаємозв'язку кримінальної відповідальності за злочини юридичної особи, відповідно до якої притягнути до кримінальної відповідальності слід одночасно і юридичну особу, і їі членів за аналогією з принципом взаємопов'язаного відшкодування в цивільному праві. Юридична особа - це органічне ціле, що складається із фізичних осіб. Діяльність юридичних осіб здійснюється через свідому діяльність людини для ефективної протидії злочинам юридичної особи. Окрім притягнення її до кримінальної відповідальності, слід притягати до кримінальної відповідальності їі представників, які відіграють важливу роль у вчиненні злочину. Підставою притягнення до кримінальної відповідальності є їх об’єктивне діяння (дія чи бездіяльність) як представника юридичної особи та їх суб'єктивна вина (умисел чи необережність) [6, с. 32].

До злочинів, за які мають нести кримінальну відповідальність юридичні особи, законодавець відніс «Легалізацію (відмивання) доходів, одержаних злочинним шляхом» (ст. 209 КК України), «Використання коштів, здобутих від незаконного обігу наркотичних засобів, психотропних речовин, їх аналогів, прекурсорів, отруйних чи сильнодіючих речовин, або отруйних чи сильнодіючих лікарських засобів» (ст. 306 КК України), «Підкуп службової особи юридичної особи приватного права незалежно від організаційно- правової форми» (ч.ч. 1 і 2 ст. $368^{3}$ КК України), «Підкуп особи, яка надає публічні послуги» (ч.ч. 1 і 2 ст. $368^{4}$ КК України), «Пропозиція, обіцянка або надання неправомірної вигоди службовій особі» (ст. 369 КК України), «Зловживання впливом» (ст. $369^{2}$ КК України). Всі чудово розуміють, що йдеться про діяльність конкретних фізичних осіб, а не юридичних [5].

Воля юридичної особи формується та виражається у рішеннях іiі одноособових або колегіальних органів, уповноважених представниках, які можуть від імені юридичної особи набувати права та виконувати обов'язки. Виникає ситуація, за якої суб'єктом права є юридична особа, однак діяльність такого суб'єкта здійснюється лише за допомогою діяльності людини. Звідси очевидно, що така правова конструкція допускає наявність двох суб'єктів: юридичної особи, яка може бути суб'єктом пасивного права та бере на себе обов'язки, що випливають зі змісту управлінської діяльності її органів, і їі уповноважених представників, які виконують організаційно-розпорядчі та адміністративно-господарські функції, можуть бути суб'єктами активного права, тобто виконувати у межах своєї компетенції обов'язки для організації. Виникає своєрідне «замкнуте коло» - юридична особа відповідальна за діяльність своїх органів, а їі уповноважені представники - за діяльність юридичної особи.

Відомості про юридичну особу, щодо якої можуть застосовуватися заходи кримінально-правового характеру, вносяться слідчим або прокурором до Єдиного реєстру досудових розслідувань негайно після вручення уповноваженій особі такої юридичної особи повідомлення про підозру у вчинені будь-якого із злочинів, передбачених ч. 1 ст. 963 КК України [5].

Про внесення таких відомостей слідчий або прокурор зобов'язаний не пізніше наступного дня письмово повідомити юридичну особу. Провадження щодо юридичної особи здійснюється одночасно 3 відповідним кримінальним провадженням, у якому особі повідомлено про підозру.

Під час здійснення досудового розслідування та судового провадження представником юридичної особи може бути адвокат, керівник юридичної особи чи інша особа, уповноважена законом або установчими документами, а також їі працівник, повноваження якого підтверджується довіреністю.

Водночас обсяг прав представника в кримінальному проводженні є однаковий незалежно від того, хто саме є представником юридичної особи: адвокат або інша уповноважена особа юридичної особи.

3 метою забезпечення конфіскації майна як виду заходу кримінально-правового характеру, а також стягнення з юридичної особи неправомірно отриманої вигоди на майно юридичної особи може бути накладено арешт. 
Кримінальне право та кримінологія. Кримінально-виконавче право. Кримінальний процес та криміналістика. Судова експертиза. Оперативно-розшукова діяльність. Судоустрій. Прокуратура та адвокатура.

3 аналізу норм Кримінального процесуального кодексу України можна зробити висновок, що такий арешт може бути накладений тільки на юридичну особу, щодо якої здійснюється провадження, тобто після повідомлення уповноваженій особі такої юридичної особи повідомлення про підозру та внесення відповідних відомостей про юридичну особу до Єдиного реєстру досудових розслідувань.

Розгляд клопотання про арешт майна юридичної особи здійснюється слідчим суддею за участю представника такої юридичної особи.

Ще однією особливістю кримінального провадження у справах щодо застосування заходів кримінально-правового характеру до юридичної особи є те, що укладення угоди про примирення та про визнання винуватості у кримінальному провадженні щодо уповноваженої особи юридичної особи, яка вчинила кримінальне правопорушення, у зв'язку з яким здійснюється провадження щодо юридичної особи, не допускається.

Висновки. 3 огляду на вищенаведене варто визнати, що зміни, які вносяться сьогодні в Кримінальний кодекс України, засновані не на наукових підходах і є дещо хаотичними та безсистемними, що призводить до руйнування основних теоретичних конструкцій у науці кримінального права. На нашу думку, доцільно було б доповнити систему покарань судовим наглядом за діяльністю юридичної особи на певний строк. Таким чином, проблема визнання юридичної особи суб'єктом злочину є неоднозначною, що зумовлено ії̈ співвідношенням з фундаментальними принципами кримінального права та кримінально-правовим статусом суб'єкта злочину. Загалом зміни, внесені до Кримінального кодексу України, є прогресивними, проте потребують доопрацювання та подальшого законодавчого врегулювання з урахування зарубіжного досвіду.

\section{Список використаних джерел}

1. Келина С. Г. Ответственность юридических лиц в проекте нового УК РФ. Уголовное право: новые идеи / за ред. С. Г. Келина. Москва, 1994. С. 50-60.

2. Судова справа: підприємство за гратами: веб-сайт. URL : http://jurist.ua/?article/368 (дата звернення: 10.02.2020).

3. Крылова Н. Е. Уголовная ответственность юридических лиц во Франции: предпосылки возникновения и основные черты. Вестник Московского университета. 1998. № 3. С. 69-80.

4. Михайлов О. О. Юридична особа як суб'єкт злочину: іноземний досвід та перспективи його застосування в Україні : автореф. дис. ... канд. юрид. наук : 12.00.08. Київ, 2008. 18 с.

5. Кримінальний кодекс України : Закон України від 5 квітня 2001 р. № 2341-III. Biдомості Верховної Ради. 2001. № 25-26. С. 131.

6. Пан Дунмэй. Теория уголовной ответственности юридических лиц в КНР. Уголовное право. 2009. № 2. С. $30-35$.

\section{References}

1. Kelina, S.G. (1994). Otvetstvennost yuridicheskih lits v proekte novogo UK RF [Responsibility of legal entities in the draft of the new Criminal Code]. Moscow [in Russian].

2. Bogatyr, V. (2013). Sudova sprava: pidpriyemstvo za gratamy [Litigation: Enterprise behind bars] Retrieved from http://jurist.ua/?article/368 [in Ukrainian].

3. Krylova, N.E. (1998). Ugolovnaya otvetstvennost yuridicheskih lits vo Frantsii: predposilki voznikniveniya i osnovnie cherty [Criminal liability of legal entities in France: prerequisites and the main features]. Vestnik Moskovskogo universiteta - Bulletin of the Moscow University, 3, 69-80 [in Russian].

4. Mikhailov, O.O. (2008). Yuridichna osoba yak subyekt zlochinu: inozemniy dosvid ta perspektivi yogo zastosuvannya v Ukraini [Legal entity as a subject of crime: foreign experience and prospects of its application in Ukraine]: Extended abstract of candidate's thesis. Kiev [in Ukrainian].

5. Kriminalnyi kodeks Ukrainy [Criminal Code Ukraine]. (2001, April 05). Vidomosti Verkhovnoi Rady Ukrainy Bulletin of Verkhovna Rada of Ukraine. Kyiv: Parlam. vyd-vo [in Ukrainian].

6. Mr Dunmei, (2013). Teoriya ugolovnoj otvetstvennosti juridicheskih lits KNR [The Theory of Criminal Liability of Legal Entities in the PRC]. Ugolovnoye pravo - Criminal Law, 1, 30-35 [in Ukrainian].

Стаття надійшла до редакції 11.02.2020. 